\title{
The influence of short-term cold stress on the metabolism of non-structural carbohydrates in polar grasses
}

\author{
Elżbieta ŁOPIEŃSKA-BIERNAT ${ }^{1 *}$, Marta PASTORCZYK², Irena GIEŁWANOWSKA ${ }^{2}$, \\ Krystyna ŻÓłTOWSKA ${ }^{1}$, Robert STRYIŃSKI ${ }^{1}$ and Ewa ZAOBIDNA ${ }^{1}$ \\ ${ }^{1}$ Department of Biochemistry, Faculty of Biology and Biotechnology, \\ University Warmia and Mazury in Olsztyn, Oczapowskiego 1A, 10-719 Olsztyn, Poland \\ 2 Department of Plant Physiology, Genetics and Biotechnology, \\ Faculty of Biology and Biotechnology, University Warmia and Mazury in Olsztyn, \\ Oczapowskiego 1A, 10-719 Olsztyn, Poland \\ * corresponding author <ela.lopienska@uwm.edu.pl>
}

\begin{abstract}
Plants adapt to extremely low temperatures in polar regions by maximizing their photosynthetic efficiency and accumulating cryoprotective and osmoprotective compounds. Flowering plants of the family Poaceae growing in the Arctic and in the Antarctic were investigated. Their responses to cold stress were analyzed under laboratory conditions. Samples were collected after $24 \mathrm{~h}$ and $48 \mathrm{~h}$ of cold treatment. Quantitative and qualitative changes of sugars are found among different species, but they can differ within a genus of the family Poaceae. The values of the investigated parameters in Pоа annua differed considerably depending to the biogeographic origin of plants. At the beginning of the experiment, Antarctic plants were acclimatized in greenhouse characterized by significantly higher content of sugars, including storage reserves, sucrose and starch, but lower total protein content. After $24 \mathrm{~h}$ of exposure to cold stress, much smaller changes in the examined parameters were noted in Antarctic plants than in locally grown specimens. Total sugar content and sucrose, starch and glucose levels were nearly constant in $P$. апnиa, but they varied significantly. Those changes are responsible for the high adaptability of $P$. аnnua to survive and develop in highly unsupportive environments and colonize new regions.
\end{abstract}

Key words: Arctic, Antarctic, cold stress, carbohydrates, enzymes, Poaceae, polar plants.

\section{Introduction}

The Arctic and the Antarctic are the least anthropogenically modified ecosystems on Earth due to their remote geographic location and extreme climate. Extensive research was conducted in those regions focused on global climate changes which have been observed in the last decades and which indirectly 
influence the distribution of plant species in the tundra (Grobe et al. 1997; Bjorkman et al. 2017).

Main abiotic factors that significantly influence polar plants include short duration of growing season, low temperature, low moisture, high salinity and high radiation stress (Alberdi et al. 2002; Block et al. 2009; Taran et al. 2012). In the evolutionary process, polar plants have developed specific anatomic and physiological features that enable them to survive in unsupportive environments and colonize areas uncovered by melting glaciers (Giełwanowska 2005; ZủñigaFeest et al. 2009; Giełwanowska et al. 2011a,b). Plants adapt to extremely low temperatures in polar regions by maximizing their photosynthetic efficiency (Xiong et al. 2000) and accumulating cryoprotective and osmoprotective compounds (Janská et al. 2010). They have developed two main mechanisms of tolerance to low, namely prevention of freeze damage to tissues and formation of ice crystals in the extracellular matrix to prevent damage of cellular structures. Supercooling, a process by which cells prevent liquids from solidifying below their freezing point, is a strategy that is widely deployed by plants in polar regions (Reyes-Diaz et al. 2006). Cryoprotective and osmoprotective compounds include amino acids (proline), proteins (HSP, LEA, PR, dehydrins) and sugars, mainly sucrose, raffinose family oligosaccharides and other polyols (Lineberge and Steponkus 1980; Newsted et al. 1991; Solhaug and Aares 1994; Hare and Cress 1997; Reyes et al. 2003; Bravo and Griffith 2005; Olave-Concha et al. 2005; Piotrowicz-Cieślak et al. 2005; Janská et al. 2010). The mechanism responsible for the protective effects of carbohydrates on proteins, biological membranes and cytoplasmic structures during dehydration has been extensively studied during freezing temperature. Sugars exert a protective influence by replacing water with hydroxyl groups to maintain hydrophilic interactions of phospholipid molecules of membranes and proteins. Carbohydrates have the ability to transform the cytoplasm into a glassy state i.e., membrane rigidification (Hoekstra et al. 2001; Reyes-Diaz et al. 2006). The glassy state protects cell structures against damage, and it stabilizes macromolecules (Koster 1991; Buitink and Leprince 2004).

Studies of the adaptive strategies of plants inhabiting extreme polar regions focuse mainly on species such as Colobantus quitensis (Kunth) Bartl. and Cerastium arcticum Ange. of the family Caryophyllace and grasses such as Deschampsia antarctica Desv., Poa arctica R. Br. and Poa annua L. which have developed specific metabolic mechanisms adapted to very low temperature. Those plants have been the object of many studies, including experiments investigating the role of sugars during cold acclimation (Piotrowicz-Cieślak et al. 2005; Convey and Smith 2006; Parnikoza et al. 2009; Olech et al.2011; Parnikoza et al. 2011; Pastorczyk et al. 2014; Kellmann-Sopyła et al. 2015).

Less is known about enzymes that participate in carbohydrate metabolism and their responses to chill stress. Present investigation focused mainly on sucrose metabolizing enzymes, synthases and invertases, which are responsible for sucrose 
levels in plants and play an important role in protection against cold stress (Guy et al. 1992; Bascuňán-Godoy et al. 2006). Amylases, glycosidases that decompose starch, one of the main reserve materials in plants, supply low-molecular-weight oligosaccharides and glucose, which maintain the osmolarity of intracellular fluid. Recent research has expanded our understanding of the functions played by sucrose and monosaccharides in sugar sensing and signaling in plants (Roitsch and Gonzalez 2004; Rolland et al. 2006; Proels and Hückelhoven 2014). Those mechanisms enable sugardecomposing enzymes to control metabolic processes and defense responses (Dorion et al. 1996; Bonfig et al. 2010).

There are three types of invertase isoenzymes that differ in their localization in plants (EC 3.2.1.26): vacuolar invertases (Inv-v), cell wall invertases (Inv-cw) and cytoplasmic invertases (Inv-c). Inv-v and Inv-cw have similar properties, and their activity is optimized in an acidic environment $(\mathrm{pH} 5.0-5.5$ and $\mathrm{pH} 3.5-5$, respectively). Both enzymes are $\beta$-fructofuranosidases which break down sucrose and, less effectively, other fructofuranosides such as stachyose and raffinose. Inv-v is important for osmoregulation, whereas Inv-cw regulates the distribution of sugars, mainly sucrose, in plants. Inv-c is active under alkaline conditions ( $\mathrm{pH}$ 6.8-8.0), and it is also referred to as neutral invertase. This sucrose-specific enzyme is strongly inhibited by high concentrations of its hydrolysis products, glucose and fructose (Roitsch and Gonzalez 2004). The multitude of mechanisms that regulate invertase expression and activity indicate that those enzymes play a very important role in the metabolism, development and defense responses of plants (Bournay et al. 1996; Cheng et al. 1999; Rojo et al. 2003; Rausch and Greiner 2004; Roitsch and Gonzalez 2004).

Plants contain three types of amylases: $\alpha$-amylase (EC 3.2.1.1), $\beta$-amylase (EC 3.2.1.2) and $\gamma$-amylase, also known as glucoamylase or amyloglucosidase, (EC 3.2.1.3), which differ in their mechanism of action and the location of the hydrolyzed glycoside bond. All amylases hydrolyze $\alpha-1,4$-glycoside bonds in starch (Beck and Ziegler 1989). Alpha-amylase plays the most important role. Depending on reaction time, $\alpha$-amylase yields products characterized by different degree of glucose polymerization, including dextrins, oligosaccharides, maltose (which is also the main product of $\beta$-amylase) and glucose. Amylases degrade starch and increase the concentrations of soluble sugars in plants which act as osmolytes. Research has demonstrated that amylases are involved in low temperature tolerance, which is an important trait in polar plants (Vecchia et al. 1998; Kratsch and Wise 2000). Coldinduced changes in soluble carbohydrates have been identified in selected polar species of the families Poaceae (Poa arctica vivipara L., Deschampsia antarctica) and Caryophyllaceae (Cerastium arvense, L., Colobanthus quitensis) (Pastorczyk et al. 2014; Kellmann-Stopyła et al. 2015). Five other species (ecotypes) of the family Poaceae (Festuca brachyphylla Schultes, Deschampsia alpina (L.) Roem. et Schult., Deschampsia cespitosa (L.) Beauv, Poa alpina L. and Poa annua) were investigated in this experiment. The aim of this study was to analyze the content 
and composition of carbohydrates and the activity of two main enzymes (amylase and invertase) which initiate the hydrolytic degradation of reserve sugars, starch and sucrose, in the shoots of plants of the family Poaceae harvested in polar regions, and to describe their responses to cold stress. The evaluated parameters were compared in Pоа аппиа plants harvested in the Antarctic and in the Olsztyn area to analyze their adaptive strategies based on sugar metabolism.

\section{Material and methods}

Material. - The experiment was performed on flowering plants of the family Poaceae growing in the Arctic and the Antarctic. Live Poa annua plants (designated A) were harvested in 2010 in the area of the Henryk Arctowski Polish Antarctic Station on King George Island (South Shetland Islands) $\left(62^{\circ} 09^{\prime} \mathrm{S}\right.$ and $58^{\circ} 28^{\prime} \mathrm{W}$ ) (Fig. 1A), whereas Festuca brachyphylla, Deschampsia alpina, Deschampsia cespitosa and Poa alpina plants were collected near the Stanistaw

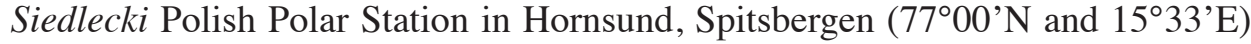
(Fig. 1B-F). The sixth studied ecotype was Poa апnиа (designated O) growing in the area of Olsztyn, Poland (53 $46^{\prime} \mathrm{N}$ and $\left.20^{\circ} 29^{\prime} \mathrm{E}\right)$.

The harvested specimens were planted individually in pots filled with horticultural soil and grown at a temperature of $18-20^{\circ} \mathrm{C}$, in the presence of daylight in the experimental greenhouse of the Faculty of Biology and Biotechnology of the University of Warmia and Mazury in Olsztyn (Fig. 1B-F).

Plant responses to cold stress were evaluated under controlled laboratory conditions. Twenty-four hours after transfer to the laboratory $\left(19-20^{\circ} \mathrm{C}\right)$, plants were placed in an incubator (Heraeus, BK6160, Kendro Laboratory Products) at a constant temperature of $20^{\circ} \mathrm{C}$ and $20 / 4 \mathrm{~h}$ photoperiod (light/dark) which corresponds to the length of day during the growing season in polar regions. After 24 hours of acclimatization, plants were exposed to cold stress at $4^{\circ} \mathrm{C}$ for 2 days. Samples for analysis were collected from shoots before (control, $0 \mathrm{~h}$ ), $24 \mathrm{~h}$ and $48 \mathrm{~h}$ after exposure to cold stress. Samples of $P$. апnиa (A) were collected only after $24 \mathrm{~h}$ due to a small number of specimens. The experiment was conducted in three replications. One sample was composed of shoot tissues from 5-10 plants. Three analytical samples of $3 \mathrm{~g}$ each were prepared from each sample and stored at $-80^{\circ} \mathrm{C}$.

Preparation of plant extracts. - Plant extracts were prepared by homogenizing $3 \mathrm{~g}$ analytical samples of plant tissues in $30 \mathrm{ml}$ of PBS (Phosphate Buffered Saline) on ice at 35,000 rpm according to modified method of Sung et al. (1989). Half of the homogenate was centrifuged for 15 minutes at $12,000 \times \mathrm{g}$ at a temperature of $4^{\circ} \mathrm{C}$. The resulting supernatant (supernatant 1) was used to determine total protein content and enzyme activity. The second half of the 


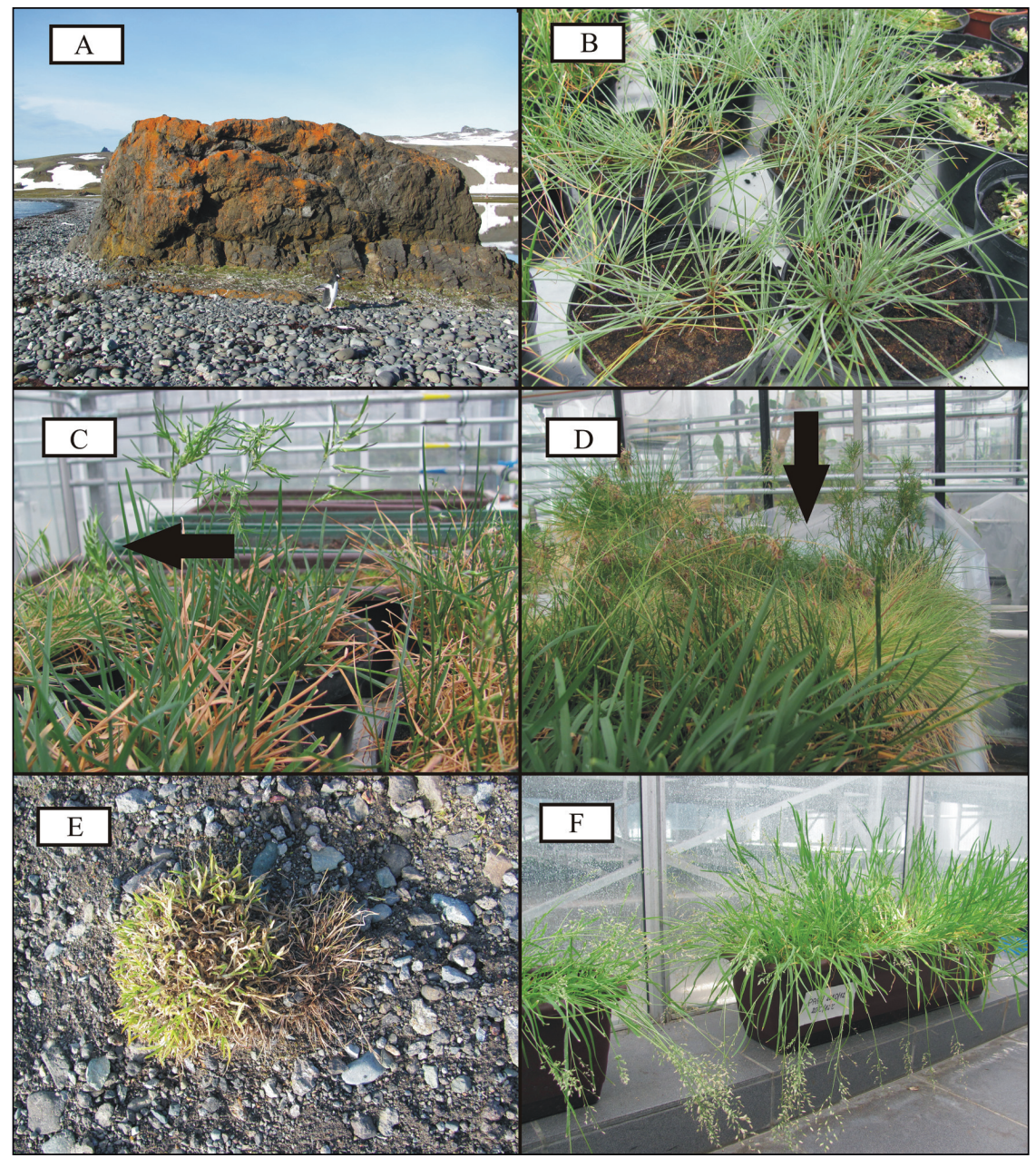

Fig. 1. The polar flowering plants of the family Poaceae under study. King George Island, neighborhood of the Henryk Arctowski Polish Antarctic Station (A), Festuca brachyphylla (B), Deschampsia alpina (arrow) (C), Poa alpina var. vivipara with viviparous culms, Deschampsia cespitosa (arrow) (D) and Poa anua in the Antarctic (E) and in the experimental greenhouse (F).

supernatant was heated at $90^{\circ} \mathrm{C}$ for 15 minutes to dissolve starch, precipitate proteins and deactivate enzymes. The homogenate was cooled and centrifuged as above. The resulting supernatant (supernatant 2) was used to determine the concentrations of starch and soluble carbohydrates.

Determination of protein content. - Protein content was determined by the method proposed by Bradford (1976) in 5-fold diluted supernatant. The protein content of the sample was read from the calibration curve for bovine serum albumin (Sigma-Aldrich) with the concentration of $500 \mu \mathrm{g} / \mathrm{mL}$. 
Determination of protein content. - Total sugar content was determined by the anthrone method (Morse 1947). Samples were diluted 100-fold. Sugar concentrations were read from the calibration curve for glucose solution $(50 \mu \mathrm{g} / \mathrm{mL}$ ) (Sigma-Aldrich) and were expressed in $\mathrm{mg}$ per $\mathrm{g}$ of fresh weight of tissue (ft).

Determination of starch content. - Starch content was determined by the modified method proposed by Sölling and Esmann (1975), which involves the measurement of the quantity of glucose released from endogenous starch by exogenous amyloglucosidase to the reaction environment. $10 \mu \mathrm{L}$ of the supernatant was transferred to square pieces $(1.5 \times 1.5 \mathrm{~cm})$ of Whatman 3 filter paper and left to dry at room temperature. Filter paper was placed in test tubes and soaked with $3 \mathrm{~mL}$ of cold $66 \%$ ethanol with the addition of $10 \%$ TCA for 20 minutes. The liquid was removed, filter paper was rinsed twice with cold $66 \%$ ethanol, and the samples were left to stand for 20 minutes each time. In the end, filter paper was rinsed for 10 minutes in cold acetone. Filter paper was dried, cut into pieces and quantitatively transferred to dry test tubes. Every test tube was filled with $0.5 \mathrm{~mL}$ of $0.2 \mathrm{M}$ acetate buffer with $\mathrm{pH} 4.8$ and $30 \mu \mathrm{l}$ (containing $25.8 \mathrm{mU}$ ) of Rhizopus amyloglucosidase solution (Sigma-Aldrich), and incubated at $37^{\circ} \mathrm{C}$ for 30 minutes. Glucose released by the enzyme during starch hydrolysis was identified with the Oxy-Glucose glucose assay kit (Pointe Scientific, Poland). Starch content was read from the calibration curve for potato starch standard $(1 \mathrm{mg} / \mathrm{mL})$ (Sigma-Aldrich) which was handled in the same manner as the analyzed samples. Starch content was expressed in $\mathrm{mg}$ per $\mathrm{g}$ of $\mathrm{ft}$.

Determination of glucose content. - Glucose content was determined with the Oxy-Glucose glucose assay kit (Pointe Scientific, Poland) according to the manufacturer's instructions.

Determination of soluble sugar content by HPLC. - Sample preparation: $0.5 \mathrm{~mL}$ of the supernatant was combined with $1 \mathrm{~mL}$ of cold $\left(-18^{\circ} \mathrm{C}\right) 96 \%$ ethanol. The mixture was stirred and left to stand at $4^{\circ} \mathrm{C}$ for 30 minutes, after which it was centrifuged at $12,000 \times \mathrm{g}$ for 6 minutes. The resulting supernatant was poured into dry test tubes and incubated at $50^{\circ} \mathrm{C}$ until solvent evaporation. Dried samples were stored in a desiccator at room temperature until analysis.

Chromatography: The sediment was dissolved in $0.5 \mathrm{~mL}$ mixture of acetonitrile and deionized water (3:2), passed through the Alltech Micro-Spin ${ }^{\circledR}$ Filter Tubes nylon filter $(0.2 \mu \mathrm{m})$ (Deerfield, Ireland) and centrifuged at $12,000 \times \mathrm{g}$ for 1 minute. $30 \mu \mathrm{L}$ of the supernatant was applied onto a chromatography column.

Carbohydrates were separated in the Shimadzu HPLC SCL-10A (Kyoto, Japan) chromatography system, on a $4.6 \times 250 \mathrm{~mm}$ High Performance Carbohydrate Column (Shimadzu) with a $3.9 \times 20 \mathrm{~mm}$ Sentry ${ }^{\mathrm{TM}}$ High 
Performance Carbohydrate Guard Column (Shimadzu). Carbohydrates were analyzed with the use of the Shimadzu RID-10A refractometer. The mobile phase was a solution of acetonitrile and deionized water (3:2). Separation was carried out at a flow rate of $1 \mathrm{~mL} / \mathrm{min}$ and temperature of $35^{\circ} \mathrm{C}$. Sugars were identified based on their retention times. They were determined quantitatively by comparing the peak area from the sample elution curve with the peak area of reference standards in the Chromax 2004 program for processing chromatographic data (POL-LAB Artur Dzieniszewski, Poland). The results were expressed in mg of sugar per $g$ of $\mathrm{ft}$.

Determination of enzyme activity. - Amylase activity was determined by the modified method proposed by Caraway (1959) based on the decrease in the color intensity of the starch-iodine solution. The experimental samples contained $50 \mu \mathrm{L}$ of the tested supernatant, $0.85 \mu \mathrm{L}$ of $0.2 \mathrm{M}$ acetate buffer with $\mathrm{pH} 4.8$ and $0.1 \mathrm{~mL}$ of $1 \%$ potato starch solution (Sigma-Aldrich). They were incubated at $37^{\circ} \mathrm{C}$ for 120 minutes. Control samples containing $0.85 \mathrm{~mL}$ of acetate buffer and $0.1 \mathrm{~mL}$ of $1 \%$ starch solution were incubated simultaneously with the experimental samples. They were combined with $50 \mu \mathrm{L}$ of the supernatant after incubation. Immediately after incubation, all samples were combined with $4 \mathrm{ml}$ of 10-fold diluted iodide in potassium iodide solution. Absorbance was read immediately at a wavelength of $650 \mathrm{~nm}$. The results were expressed in $\mu \mathrm{g}$ of decomposed starch per mg of protein.

Invertase activity was determined by the method proposed by Dahlquist (1968) and Bonfig et al. (2010) by measuring the amount of glucose released by the enzyme from the sucrose substrate at $\mathrm{pH} 4.8$ and $\mathrm{pH}$ 6.8. Glucose was determined with an enzymatic assay kit (Pointe Scientific, Poland). Enzyme activity was expressed in $\mathrm{U}$ per $\mathrm{mg}$ of protein.

Statistical analysis. - The results were analyzed statistically in the Statistica 10.0 program (StatSoft Inc.). Significant differences between means $(\mathrm{p} \leq 0.05)$ were determined by ANOVA, followed by Tukey's test.

\section{Results}

The protein content of vegetative tissues in control plants was determined in a broad range of $0.48 \mathrm{mg} / \mathrm{g}$ in $P$. апnиа (A) to $16.56 \mathrm{mg} / \mathrm{g} \mathrm{ft}$ in $F$. brachyphylla. Mean values differed significantly between species. The only exception was protein content which was similar in both species of the genus Deschampsia (Fig. 2). Cold stress $\left(4^{\circ} \mathrm{C}\right.$ for $\left.24 \mathrm{~h}\right)$ led to a significant increase in protein concentrations in P. annua plants harvested in both Antarctic (A) and Olsztyn (O). The protein content of D. alpina, D. cespitosa and P. alpine decreased relative 


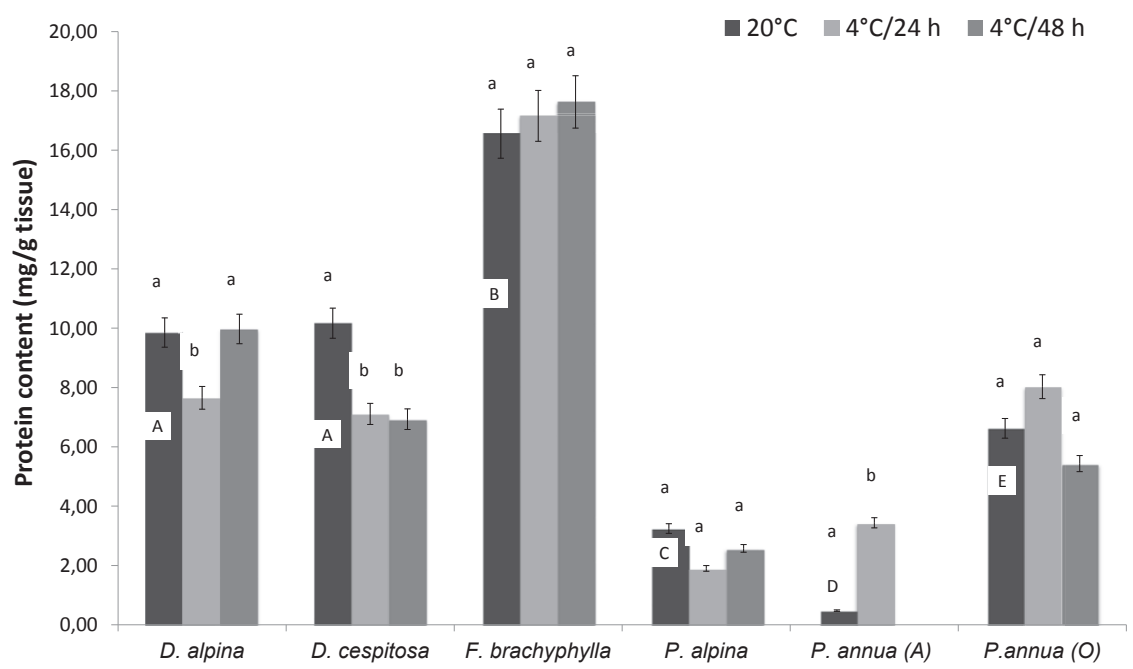

Fig. 2. Changes in the content of protein $(\mathrm{mg} / \mathrm{g}$ fresh tissue) in shoots of polar Poaceae plants growing at $20^{\circ} \mathrm{C}$ (control, $0 \mathrm{~h}$ ) and at $4^{\circ} \mathrm{C}$ (chilling stress).

Explanation: Mean $\pm \mathrm{SD}$, values are means of three replicates, each of them consists material from five plants. The same capital letters in the column indicate no significant differences $(\mathrm{P}<0.05)$ between means of studied species controls. The same small letters in the column indicate no significant differences $(\mathrm{P}<0.05)$ between means of protein for the same species depended of time treatment at $4^{\circ} \mathrm{C}$.

to control plants. After $48 \mathrm{~h}$ of exposure to cold stress, significant differences in protein content were not observed between control and experimental plants, excluding D. cespitosa and P. апnиa (A) (Fig. 2).

The total sugar content of control plants from each species also differed significantly and ranged from $17.9 \mathrm{mg} / \mathrm{g}$ to $54.0 \mathrm{mg} / \mathrm{g}$ ft (Fig. 3). The noted difference was not statistically significant $(\mathrm{p}=0.072)$ only between $D$. alpina and P. апnиа $(\mathrm{O})$. Significant changes induced by cold stress were not noted in D. alpina and P. аnnua (A). Cold stress lowered the total carbohydrate content of $D$. cespitosa and $P$. alpina. Similar changes were noted after $24 \mathrm{~h}$ in $P$. апnиa $(\mathrm{O})$, whereas an increase in carbohydrate concentrations was observed in $F$. brachyphylla. Sugar concentrations in both P. annua (O) and F. brachyphylla returned to control group levels after $48 \mathrm{~h}$ of cold stress (Fig. 3).

The control samples of the evaluated species also differed in the levels of different soluble sugars (Table 1). After $24 \mathrm{~h}$ of storage at $4^{\circ} \mathrm{C}$, changes in sucrose concentrations were not observed, except in P. alpina and P. annua $(\mathrm{O})$, whereas after $48 \mathrm{~h}$, sucrose levels increased significantly in D. alpina, D. cespitosa, $F$. brachyphylla and $P$. апnua $(\mathrm{O})$ (Table 1$)$. The noted differences in sucrose levels were not always accompanied by the corresponding changes in hexoses free glucose and fructose (Table 1). The remaining sugars were not identified in 


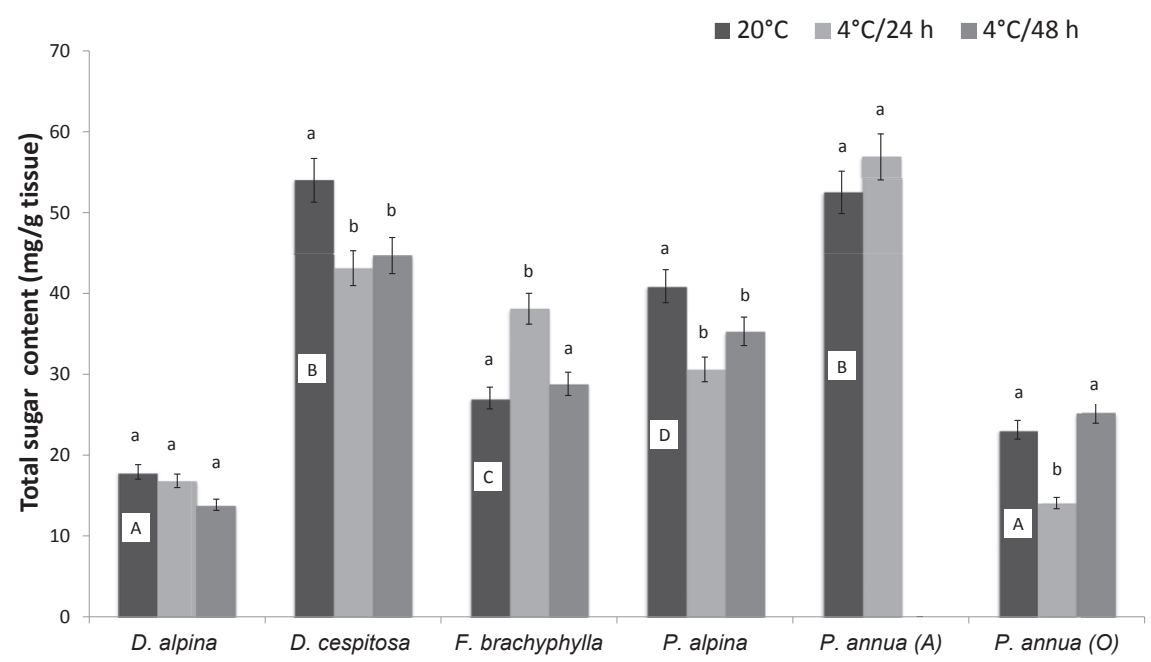

Fig. 3. Changes in the content of total sugars ( $\mathrm{mg} / \mathrm{g}$ fresh tissue) in shoots of polar Poaceae plants growing at $20^{\circ} \mathrm{C}$ (control, $0 \mathrm{~h}$ ) and at $4^{\circ} \mathrm{C}$ (chilling stress). Explanation the same as in Fig. 2.

all species. Raffinose was detected only in D. cespitosa, and its concentrations increased significantly after $48 \mathrm{~h}$ of cold stress (Table 1 ). The presence of ribose was noted in control plants of three species, and its concentrations were highest after $24 \mathrm{~h}$ of cold storage (Table 1). The analyzed plants also contained other polyols - glycerol and myo-inositol. Glycerol was present in all species, and its concentrations were similar in control samples (Table 1). Glycerol levels increased after $48 \mathrm{~h}$ of exposure to cold stress in D. cespitosa and F. brachyphylla, and already after $24 \mathrm{~h}$ in $P$. апnиa (A) and $P$. апnиa (O). Myo-inositol was detected in F. brachyphylla and P. annua (A), and it was less abundant in experimental than in control plants (Table 1).

The evaluated plant species were divided into two groups based on their starch content. The first group comprised plants with low starch levels $(3.1 \mathrm{mg} / \mathrm{g}$ wt to $4.0 \mathrm{mg} / \mathrm{g} \mathrm{ft}$ ): D. alpina, F. brachyphylla and P. annua (O) (Fig. 4). Plants from the second group, D. cespitosa, $P$. alpina and $P$. annua (A), were more abundant in starch $(6.2 \mathrm{mg} / \mathrm{g}$ to $9.2 \mathrm{mg} / \mathrm{g} \mathrm{ft}$ ) (Fig. 4). Cold stress did not induce significant changes in starch concentrations, and the only exception was a transient (after $24 \mathrm{~h}$ ) decrease in starch levels in P. апnиа (O) (Fig. 4).

Amylase activity was very low, except in D. alpina, F. brachyphylla and P. alpina, and it was further decreased in most species after 24 of cold stress. After $48 \mathrm{~h}$ of cold storage, amylase activity increased significantly relative to the level noted after 24 h except D. alpina (Fig. 5). Under control conditions, invertase activity was minimal at $\mathrm{pH} 4.8$ (data not shown). At $\mathrm{pH} 6.8$, invertase activity was high in D. alpina, P. alpina and P. annua (A), low in F. brachyphylla and very low in D. cespitosa and $P$. апnиa (O) (Fig. 6). After $24 \mathrm{~h}$ of cold stress, 
Table 1

Changes in the concentration of soluble carbohydrates ( $\mathrm{mg} / \mathrm{g}$ wet tissue) in shoots of polar Poaceae plants growing at $20^{\circ} \mathrm{C}$ (control, $0 \mathrm{~h}$ ) and at $4^{\circ} \mathrm{C}$ (chilling stress)

\begin{tabular}{|c|c|c|c|c|c|c|c|c|}
\hline Species & $\begin{array}{c}\text { Time } \\
\text { at } 4^{\circ} \mathrm{C} \\
\text { (h) }\end{array}$ & $\begin{array}{l}\text { Saccha- } \\
\text { rose }\end{array}$ & Glucose & Fructose & Ribose & Raffinose & Glycerol & $\begin{array}{c}\text { Myo- } \\
\text {-inosytol }\end{array}$ \\
\hline \multirow{3}{*}{$\begin{array}{l}\text { Des- } \\
\text { champsia } \\
\text { alpina }\end{array}$} & 0 & $\begin{array}{c}6.50 \pm \\
0.33 * \mathrm{a}, \mathrm{A}\end{array}$ & $\begin{array}{l}2.46 \pm \\
0.12^{\mathrm{a}, \mathrm{A}}\end{array}$ & $\begin{array}{l}1.80 \pm \\
0.09^{\mathrm{a}, \mathrm{A}}\end{array}$ & $\begin{array}{l}1.69 \pm \\
0.58^{\mathrm{A}}\end{array}$ & 0 & $\begin{array}{c}1.75 \pm \\
0.09^{\mathrm{ab}, \mathrm{A}}\end{array}$ & 0 \\
\hline & 24 & $\begin{array}{l}7.79 \pm \\
0.39 \mathrm{ab}\end{array}$ & $\begin{array}{c}4.30 \pm \\
0.22^{\mathrm{b}}\end{array}$ & $\begin{array}{c}3.89 \pm \\
0.19^{\mathrm{b}}\end{array}$ & 0 & 0 & $\begin{array}{c}1.81 \pm \\
0.09^{\mathrm{a}}\end{array}$ & 0 \\
\hline & 48 & $\begin{array}{c}10.08 \pm \\
0.5^{\mathrm{b}}\end{array}$ & $\begin{array}{c}2.98 \pm \\
0.15^{\mathrm{a}}\end{array}$ & $\begin{array}{l}4.37 \pm \\
0.22^{\mathrm{b}}\end{array}$ & 0 & 0 & $\begin{array}{l}1.25 \pm \\
0.06^{\mathrm{b}}\end{array}$ & 0 \\
\hline \multirow{3}{*}{$\begin{array}{l}\text { Des- } \\
\text { champsia } \\
\text { cespitosa }\end{array}$} & 0 & $\begin{array}{c}17.91 \pm \\
0.9^{\mathrm{a}, \mathrm{B}}\end{array}$ & $\begin{array}{l}1.72 \pm \\
0.09^{\mathrm{a}, \mathrm{B}}\end{array}$ & $\begin{array}{l}3.13 \pm \\
0.16^{\mathrm{a}, \mathrm{B}}\end{array}$ & 0 & $\begin{array}{c}1.37 \pm \\
0.07^{\mathrm{a}}\end{array}$ & $\begin{array}{c}0.88 \pm \\
0.04^{\mathrm{a}, \mathrm{A}}\end{array}$ & 0 \\
\hline & 24 & $\begin{array}{c}16.14 \pm \\
0.81^{\mathrm{a}}\end{array}$ & $\begin{array}{c}1.68 \pm \\
0.08^{\mathrm{a}}\end{array}$ & $\begin{array}{c}3.09 \pm \\
0.15^{\mathrm{a}}\end{array}$ & $\begin{array}{c}7.17 \pm \\
0.36\end{array}$ & $\begin{array}{l}1.28 \pm \\
0.06^{\mathrm{a}}\end{array}$ & $\begin{array}{c}1.26 \pm \\
0.06^{\mathrm{a}}\end{array}$ & 0 \\
\hline & 48 & $\begin{array}{c}31.49 \pm \\
1.57^{\mathrm{b}}\end{array}$ & $\begin{array}{c}7.80 \pm \\
0.39^{\mathrm{b}}\end{array}$ & $\begin{array}{c}8.55 \pm \\
0.43^{\mathrm{a}}\end{array}$ & 0 & $\begin{array}{c}14.69 \pm \\
0.73^{\mathrm{b}}\end{array}$ & $\begin{array}{c}4.18 \pm \\
0.21^{\mathrm{b}}\end{array}$ & 0 \\
\hline \multirow{3}{*}{$\begin{array}{l}\text { Festuca } \\
\text { brachy- } \\
\text { phylla }\end{array}$} & 0 & $\begin{array}{c}14.82 \pm \\
0.74^{\mathrm{aC}}\end{array}$ & $\begin{array}{l}3.57 \pm \\
0.18^{\mathrm{a}, \mathrm{C}}\end{array}$ & $\begin{array}{l}4.89 \pm \\
0.24^{\mathrm{a}, \mathrm{C}}\end{array}$ & $\begin{array}{c}22.35 \pm \\
1.12^{\mathrm{a}, \mathrm{B}}\end{array}$ & 0 & $\begin{array}{l}2.28 \pm \\
0.11^{\mathrm{a}, \mathrm{A}}\end{array}$ & $\begin{array}{l}3.73 \pm \\
0.19^{\mathrm{a}, \mathrm{A}}\end{array}$ \\
\hline & 24 & $\begin{array}{c}16.62 \pm \\
0.83^{\mathrm{a}}\end{array}$ & $\begin{array}{c}3.24 \pm \\
0.16^{\mathrm{a}}\end{array}$ & $\begin{array}{c}5.72 \pm \\
0.29^{\mathrm{a}}, \\
\end{array}$ & $\begin{array}{c}39.11 \pm \\
1.96^{\mathrm{b}}\end{array}$ & 0 & $\begin{array}{c}1.96 \pm \\
0.1^{\mathrm{a}} \\
\end{array}$ & $\begin{array}{c}3.08 \pm \\
0.15^{\mathrm{a}} \\
\end{array}$ \\
\hline & 48 & $\begin{array}{c}24.68 \pm \\
1.23^{\mathrm{b}}\end{array}$ & $\begin{array}{c}3.18 \pm \\
0.15^{\mathrm{a}}\end{array}$ & $\begin{array}{c}5.94 \pm \\
0.3^{\mathrm{a}}\end{array}$ & $\begin{array}{c}18.72 \pm \\
0.94^{\mathrm{a}}\end{array}$ & 0 & $\begin{array}{c}3.96 \pm \\
0.2^{\mathrm{b}}\end{array}$ & $\begin{array}{l}1.55 \pm \\
0.08^{\mathrm{b}}\end{array}$ \\
\hline \multirow{3}{*}{$\begin{array}{l}\text { Poa } \\
\text { alpina }\end{array}$} & 0 & $\begin{array}{c}1.95 \pm \\
0.1^{\mathrm{a}, \mathrm{A}}\end{array}$ & $\begin{array}{c}3.96 \pm \\
0.2^{\mathrm{a}, \mathrm{C}}\end{array}$ & $\begin{array}{l}5.84 \pm \\
0.29^{\mathrm{a}, \mathrm{C}}\end{array}$ & 0 & 0 & $\begin{array}{l}1.31 \pm \\
0.07 \mathrm{a}, \mathrm{A}\end{array}$ & 0 \\
\hline & 24 & $\begin{array}{c}16.67 \pm \\
0.83^{b}\end{array}$ & $\begin{array}{c}2.38 \pm \\
0.12^{\mathrm{b}}\end{array}$ & $\begin{array}{c}2.16 \pm \\
0.11^{\mathrm{b}} \\
\end{array}$ & 0 & 0 & $\begin{array}{c}1.09 \pm \\
0.05^{\mathrm{a}}\end{array}$ & 0 \\
\hline & 48 & $\begin{array}{c}2.60 \pm \\
0.13^{\mathrm{a}}\end{array}$ & $\begin{array}{c}11.87 \pm \\
0.59^{\mathrm{c}}\end{array}$ & $\begin{array}{c}10.82 \pm \\
0.54^{c}\end{array}$ & 0 & 0 & $\begin{array}{l}1.67 \pm \\
0.08^{\mathrm{a}} \\
\end{array}$ & 0 \\
\hline \multirow{2}{*}{$\begin{array}{l}\text { Poa } \\
\text { annua } \\
\text { (A) }\end{array}$} & 0 & $\begin{array}{c}13.22 \pm \\
0.66^{\mathrm{a}, \mathrm{C}}\end{array}$ & $\begin{array}{l}2.52 \pm \\
0.13^{\mathrm{a}, \mathrm{A}}\end{array}$ & $\begin{array}{c}18.35 \pm \\
0.92^{\mathrm{a}, \mathrm{D}}\end{array}$ & $\begin{array}{c}26.37 \pm \\
1.32^{\mathrm{a}, \mathrm{B}}\end{array}$ & 0 & $\begin{array}{l}2.68 \pm \\
0.13^{\mathrm{a}, \mathrm{A}}\end{array}$ & $\begin{array}{l}1.00 \pm \\
0.05^{\mathrm{a}, \mathrm{B}}\end{array}$ \\
\hline & 24 & $\begin{array}{c}12.86 \pm \\
0.64^{\mathrm{a}}\end{array}$ & $\begin{array}{c}1.92 \pm \\
0.1^{\mathrm{a}}\end{array}$ & $\begin{array}{c}25.44 \pm \\
1.27^{\mathrm{b}}\end{array}$ & $\begin{array}{c}41.97 \pm \\
2.1^{\mathrm{b}}\end{array}$ & 0 & $\begin{array}{c}4.28 \pm \\
0.21^{\mathrm{b}}\end{array}$ & $\begin{array}{c}0.59 \pm \\
0.03^{\mathrm{b}}\end{array}$ \\
\hline \multirow{3}{*}{$\begin{array}{l}\text { Poa } \\
\text { aпnua } \\
\text { (O) }\end{array}$} & 0 & $\begin{array}{l}9.24 \pm \\
0.46^{\mathrm{a}, \mathrm{D}}\end{array}$ & $\begin{array}{l}0.37 \pm \\
0.15^{\mathrm{a}, \mathrm{D}}\end{array}$ & $\begin{array}{l}2.68 \pm \\
0.13^{\mathrm{a}, \mathrm{B}}\end{array}$ & $\begin{array}{c}1.21 \pm \\
0.18^{\mathrm{a}, \mathrm{A}}\end{array}$ & 0 & $\begin{array}{l}1.12 \pm \\
0.06^{\mathrm{a}, \mathrm{A}}\end{array}$ & 0 \\
\hline & 24 & $\begin{array}{c}17.42 \pm \\
0.87^{\mathrm{b}}\end{array}$ & $\begin{array}{c}4.27 \pm \\
0.21^{\mathrm{b}}\end{array}$ & $\begin{array}{l}8.25 \pm \\
0.41^{\mathrm{b}} \\
\end{array}$ & $\begin{array}{c}31.63 \pm \\
1.58^{\mathrm{b}}\end{array}$ & 0 & $\begin{array}{c}3.90 \pm \\
0.2^{\mathrm{b}}\end{array}$ & 0 \\
\hline & 48 & $\begin{array}{c}14.92 \pm \\
0.75^{\mathrm{c}}\end{array}$ & $\begin{array}{c}0.97 \pm \\
0.05^{\mathrm{c}}\end{array}$ & $\begin{array}{c}5.91 \pm \\
0.3^{\mathrm{c}}\end{array}$ & $\begin{array}{c}23.41 \pm \\
1.17^{\mathrm{c}}\end{array}$ & 0 & $\begin{array}{l}3.05 \pm \\
0.15^{\mathrm{b}}\end{array}$ & 0 \\
\hline
\end{tabular}

Explanation: * mean $\pm \mathrm{SD}$, values are means of three replicates, each of them consists material from five plants. The same capital letters in the column indicate no significant differences $(\mathrm{P}<0.05)$ between means of studied species controls. The same small letters in the column indicate no significant differences $(\mathrm{P} \leq 0.05)$ between means of sugar for the same species depended of time treatment at $4^{\circ} \mathrm{C}$. 


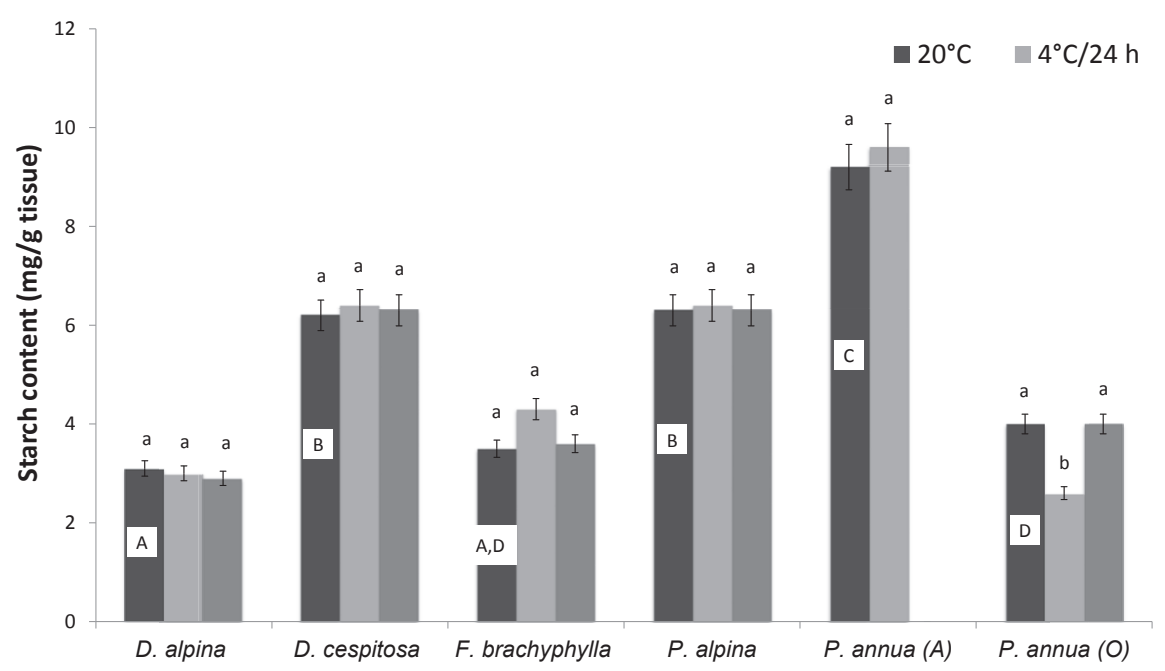

Fig. 4. Changes in the content of starch $(\mathrm{mg} / \mathrm{g}$ fresh tissue) in shoots of polar Poaceae plants growing at $20^{\circ} \mathrm{C}$ (control, $0 \mathrm{~h}$ ) and at $4^{\circ} \mathrm{C}$ (chilling stress). Explanation the same as in Fig. 2.

invertase activity decreased several fold in D. alpina and P. annua (A). After $48 \mathrm{~h}$, invertase activity increased multi-fold in $P$. annua $(\mathrm{O})$ and $F$. brachyphylla plants (Fig. 6).

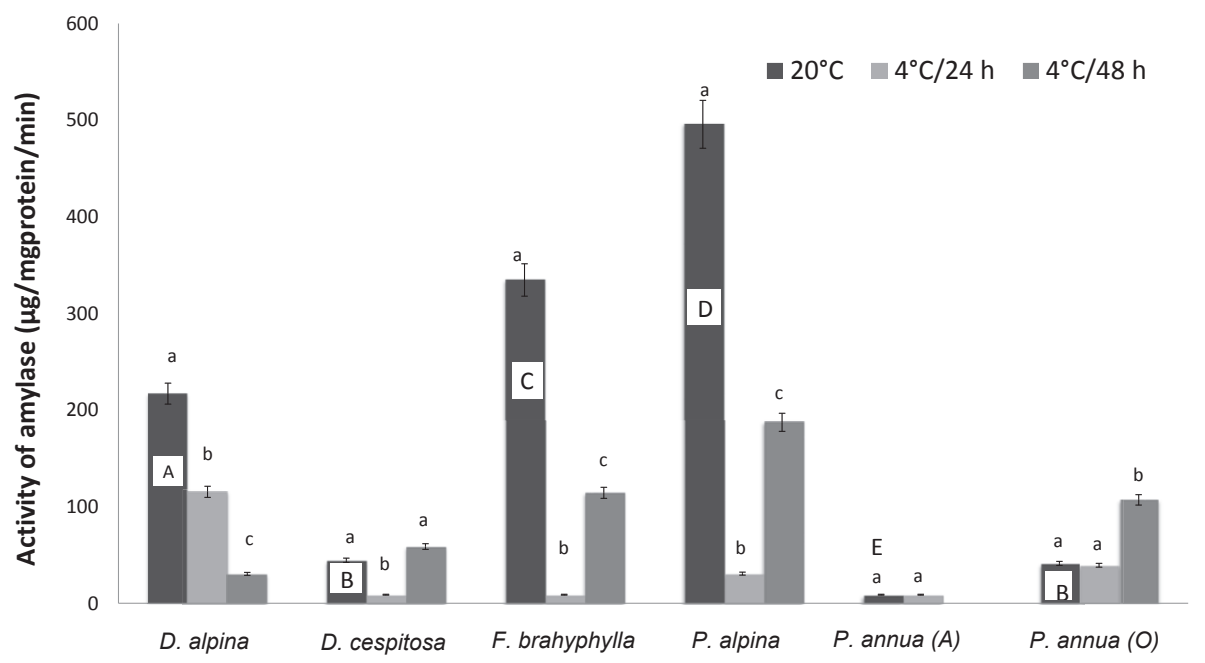

Fig. 5. Activity of amylase ( $\mu \mathrm{g} / \mathrm{mg}$ protein $/ \mathrm{min})$ in shoots of polar Poaceae plants growing at $20^{\circ} \mathrm{C}$ (control, $0 \mathrm{~h}$ ) and at $4^{\circ} \mathrm{C}$ (chilling stress). Explanation the same as in Fig. 2. 


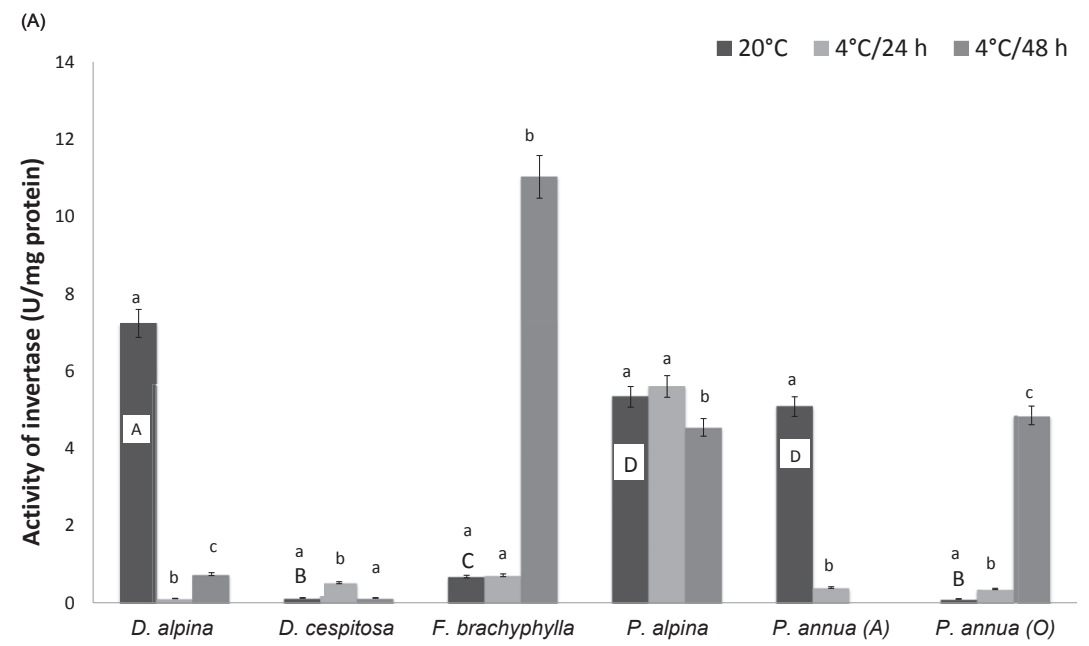

Fig. 6. Activity of invertase (U/mg protein) in shoots of polar Poaceae plants growing at $20^{\circ} \mathrm{C}$ (control, $0 \mathrm{~h}$ ) and at $4^{\circ} \mathrm{C}$ (chilling stress). Explanation the same as in Fig. 2.

\section{Discussion}

Harsh climatic conditions have caused the formation of different morphological features in vascular plants of the polar regions, which are helping them to maintain in the cold and harsh climate. These features can include first of all reduced, vertical and compact plant growth, protect the shoots by reducing the structure e.g. the loss of water from the tissues or the influence of light intensity, phenotypic plasticity of individuals of the same species living in different microhabitats and communal growth of plants. In such difficult conditions it occurs mostly to reduce to a minimum the metabolic activity of the body, and thus the processes of plant growth and development (Block et al. 2009). The presence, development, reproduction and expansion of vascular plants, including $P$. апnиa, in the Arctic and in the Antarctic, indicate that they tolerate adverse environmental conditions, including cold stress.

Carbohydrates play the same roles in plants inhabiting polar and temperate climates. Sugars act as energy reserves, signaling molecules, free radical scavengers and compounds that protect plants against abiotic and biotic stresses. In plant species native to the Antarctic geobotanical zone, the accumulation of carbohydrates is one of the key mechanisms conditioning resistance to cold stress (Zúñiga et al. 1996; Bravo et al. 2001; Piotrowicz-Cieślak et al. 2005). In the present study, control plants of grass species belonging to the same genus differed in their total sugar content (Fig. 3). The greatest, more than 2-fold differences were noted between P. апnиа plants harvested in the Antarctic and in the Olsztyn area, and those variations could be attributed to adaptive mechanisms. 
The above plants also differed in their responses after $24 \mathrm{~h}$ of exposure to cold stress (Fig. 3). Carbohydrate levels decreased in D. cespitosa, P. alpina and $P$. апnиа $(\mathrm{O})$, probably due to higher demand for energy required for adaptation to cold stress. In P. апnиa $(\mathrm{O})$, the observed decrease could be associated with starch decomposition (Table 1). In a similar experiment, Pastorczyk et al. (2015) reported an increase in sugar levels after $24 \mathrm{~h}$ of cold stress in two species of the family Caryophyllaceae (C. quitensis and C. alpinum) and two species of the family Poaceae $(D$. antarctica and $P$. arctica). The results noted by the cited authors differed from our findings, probably because Pastorczyk et al. (2015) analyzed only soluble sugars.

Non-reducing sugars, such as sucrose, raffinose and stachyose, protect plant cells by providing them with specific properties. They can be accumulated in higher concentrations because unlike monosaccharides, they do not enter into reactions with amino acids that lead to non-enzymatic glycation of proteins and peptides (Lapolla et al. 2005). Increased sucrose accumulation in the vegetative tissues of plants subjected to various environmental stressors is a well-known phenomenon. It has been observed in many cold-exposed plant species in different geographic latitudes and different stages of development, including Triticum aestivum L. seedlings (Crespi et al. 1991), Spinacia oleracea L. leaves (Guy et al. 1992) and Lolium perenne L. shoots (Bhowmik et al. 2006). Our findings (Table 1) and the results of studies analyzing the vegetative tissues and diaspores of several species of polar plants (Pastorczyk et al. 2014; Kellmann-Sopyła et al. 2015) indicate that sucrose, an osmotically active compound, is accumulated in response to cold stress. As expected, sucrose was the predominant sugar in the evaluated species (Table 1). Raffinose, one of the most important oligosaccharides with protective properties (Piotrowicz-Cieślak et al. 2005), was detected only in D. cespitosa. This is an interesting observation because the results reported by Pastorczyk et al. (2014) suggested that raffinose does not occur in polar plants of the family Poaceae. In the present study, raffinose concentrations in D. cespitosa increased in response to cold stress (Table 1). Similar results were noted by Pastorczyk et al. (2014) in Caryophyllaceae species.

Polyols, including cyclitols, are osmotically active compounds that increase plant resistance to salt stress, low temperature and soil drought (Chiera et al. 2006). Polyols stabilize cell membranes under exposure to stress (Farrar 1988; Leprince et al. 1993; Jennings and Lysek 1996). Glycerol is a major polyol found in the tissues of the analyzed plants (Table 1). In this study, a significant increase in glycerol concentrations was observed in most of the examined species (Table 1). An increase in the biosynthesis and content of glycerol was also reported in Arabidopsis thaliana (L.) exposed to salt stress (Bahieldin et al. 2014). The above observations indicate that glycerol has cryoprotective and osmoprotective properties. Myo-inositol is the most widely occurring cyclitol which is found in the cytoplasm of both plant and animal cells and in organelles 
bounded by one or two membranes (Lackey et al. 2003). In this study, myoinositol was found in only two plant species, but it could be present in the remaining plants in quantities below the method detection limit. Control plants of $F$. brachyphylla were much more abundant in myo-inositol $(3.73 \pm 0.19 \mathrm{mg} / \mathrm{g}$ wt) than $P$. апnиа (A) $(1.0 \pm 0.05 \mathrm{mg} / \mathrm{g} \mathrm{ft})$. Myo-inositol levels in vegetative tissues were nearly halved after cold storage at $4^{\circ} \mathrm{C}$. The compound was not found in the vegetative tissues of $P$. апnиa (O) (Table 1). The concentrations of myo-inositol were very low $(0.07 \pm 0.00 \mathrm{mg} / \mathrm{g} \mathrm{DW})$ in mature seeds of $P$. annua (O), and were higher in $P$. аппиа (A) $(0.50 \pm 0.02 \mathrm{mg} / \mathrm{g} \mathrm{DW})$ (KellmannSopyła et al. 2015). Myo-inositol seems to play a limited role in this species under exposure to cold stress.

Our study analyzed changes in the content of carbohydrates and their derivatives as well as changes in the activity of invertases and amylases hydrolyzing two major plant sugars in response to short-term cold stress. Sucrose is decomposed by invertase to glucose and fructose, hexoses which are a source of energy and play important anabolic and regulatory (sugar sensing) functions in plants (Van den Ende and Valluru 2009). Invertase activity was examined at $\mathrm{pH} 4.8$ and $\mathrm{pH} 6.8$. The results noted at $\mathrm{pH} 4.8$ were surprising. High levels of activity were expected because $\mathrm{pH} 4.8$ is close to the optimal values for two of the three main invertases: Inv-cw and Inv-v (Roitsch and Gonzalez 2004), whereas only minimal levels of activity were observed. This result is difficult to interpret, and it could be attributed to the release of invertase inhibitory proteins, whose presence has been noted in many plant species (Bonfig et al. 2010), during sample preparation. This observation indicates that our knowledge of invertases and their inhibitors in the analyzed group of plants is limited and should be expanded. Cytoplasmic invertase has different properties and is active at neutral pH (Roitsch and Gonzalez 2004). In this study, Inv-c activity was also low in the control plants of three species, but it increased after $24 \mathrm{~h}$ of chilling. The observed increase was significant in D. cespitosa and P. annua $(\mathrm{O})$, whereas in F. brachyphylla, a significant rise in Inv-c activity was noted only after $48 \mathrm{~h}$ (Fig. 6). In the control plants of D. alpina and P. апnиа (A) characterized by high invertase levels, the activity of Inv-c clearly decreased after $24 \mathrm{~h}$ of exposure to cold stress. In the above plants, a simultaneous increase was observed in the concentrations of glucose and fructose, the products of sucrose hydrolysis catalyzed by invertase (Table 1). Vargas et al. (2003) demonstrated that Inv-c is strongly inhibited by those compounds, which could at least partially explain the accompanying decrease in enzyme activity levels.

Similarly to invertases, the activity of amylases also differed significantly in control plants. After $24 \mathrm{~h}$ of cold stress, a transitional decrease in amylase activity was observed in most species, except $P$. апnиa (Fig. 5). As a result, starch levels remained fairly constant. 
The results of our study suggest that cold-induced changes in the content and composition of sugars are varied and species-specific, but they can differ within a genus of the family Poaceae. The values of the investigated parameters in $P$. апnиa differed considerably depending on the biogeographic origin of plants. At the beginning of the experiment, greenhouse acclimatized Antarctic plants were characterized by significantly higher content of sugars, including storage reserves, sucrose and starch, but lower total protein content. After $24 \mathrm{~h}$ of exposure to cold stress, much smaller changes in the examined parameters were noted in Antarctic plants than in locally grown specimens. Total sugar content and sucrose, starch and glucose levels were nearly constant in $P$. апnиa (A), but they varied significantly in $P$. апnиa $(\mathrm{O})$. These observations point to epigenetically programmed changes in the species' genome which are influenced by habitat conditions. Those changes are responsible for the high adaptability of $P$. апnиa which enables this cosmopolitan species to survive and develop in highly unsupportive environments and colonize new regions.

\section{References}

Alberdi M., Bravo L.A., Gutiérrez A., GideKel M. and CorCuera L. 2002. Ecophysiology of Antarctic vascular plants. Plant Physiology 115: 479-486.

Bahieldin A., Sabir J.S.M., Ramadan A., Alzohairy A.M., Younis R.A., Shokry A.M., Gadalla N.O., EdRIS S., HaSSAN S.M., Al-Kordy M.A., KAMAl K.B.H., RABAH S., ABUZINADAH O.A. and EL-DOMYATI F.M. 2014. Control of glycogen biosynthesis under high salt stress in Arabidopsis. Functional Plant Biology 41: 87-95.

BASCUŇÁN-Godoy L., URiBe E., ZỦÑIGA-FeEST A., CorCUERA L. and BraVo L. 2006. Low temperature regulates sucrose-phosphate synthase activity in Colobantus quitensis (Kunth) Bartl. by decreasing activitation by glucose-6-phosphate. Polar Biology 29: 1011-1017.

BECK E. and ZIEGLER P. 1989. Biosynthesis and degradation of starch in higher plants. Annual Review of Plant Biology 40: 95-117.

Bhowmik P.K., TAmura K., SANAda Y., TASE K. and YAmada T. 2006. Sucrose metabolism of perennial ryegrass in relation to cold acclimation. Zeitschrift für Naturforschung 61c: 99-104.

BJorkman A.D., Vellend M., Frei E.R. and Henry G.H.R. 2017. Climate adaptation is not enough: warming does not facilitate success of southern tundra plant populations in the high Arctic. Global Change Biology 23: 1540-1551.

Block W., SMITH L.R.I. and KeNNEDY A.D. 2009. Strategies of survival and resource exploitation in the Antarctic fell field ecosystem. Biology Review 84: 449-484.

Bonfig K.B., Gabler A., Simon U.K., Luschin-Ebengreuth N., HATZ M., Berger S., MuHAMMAD N., ZEIER J., SinHA A.K. and RoITSCH T. 2010. Post-translational depression of invertase activity in source leaves via down-regulation of invertase inhibitor expression is part of the plant defense response. Molecular Plant 3: 1037-1048.

Bournay A.S., Hedley P.E., Maddison A., Waugh R. and Machray G.C. 1996. Exon skipping induced by cold stress in a potato invertase gene transcript. Nucleic Acids Research 24: 2347-2351. 
BRADFORD M.M. 1976. A rapid and sensitive method for quantitation of microgram quantities of protein utilizing the principle of protein-dye-binding. Analytical Biochemistry 72: 248-54.

BRAVO L.A. and GRIFFITH M. 2005. Characterization of antifreeze activity in Antarctic plants. Journal of Experimental Botany 56: 1189-1196.

Bravo L.A., Ulloa N., ZỦÑIga G.E., Casanova A., CorCUera L.J. and Alberdi M. 2001 . Cold resistance in Antarctic angiosperms. Plant Physiology 111: 55-65.

BUITINK J. and LEPRINCE O. 2004. Glass formation in plant anhydrobiotes: survival in the dry state. Cryobiology 48: 215-228.

CARAWAY W.T. 1959. A stable starch substrate for the determination of amylase in serum and other body fluids. American Journal of Clinical Pathology 32: 97-99.

ChEng W.H., TALIERCiO E.W. and CHOUREY P.S. 1999. Sugars modulate an unusual mode of control of the cell-wall invertase gene (Incwl) through its 3' untranslated region in a cell suspension culture of maize. Proceedings of the National Academy of Sciences of the United States of America 96: 10512-10517.

Chiera J.M., Streeter J.G. and Finer J.J. 2006. Ononitol and pinitol production in transgenic soybean containing the inositol methyl transferase gene from Mesembryantheum crystalinum. Plant Science 171: 647-654.

Convey P. and SMith R.I.L. 2006. Responses of terrestrial Antarctic ecosystems to climate change. Plant Ecology 182: 1-10.

CResPi M.D., Zabaleta E.J., PonTis H.G. and SAlERnO G.L. 1991. Sucrose synthase expression during cold acclimation in wheat. Plant Physiology 96: 887-891.

DAHLQVIST A. 1969. Assay of intestinal disaccharidases. Analytical Biochemistry 22: 99-107.

DORION S., LALONDE S. and SAINI H.S. 1996. Induction of male sterility in wheat by meiotic-stage water decline is preceded by a decline in invertase activity and changes in carbohydrate metabolism in anthers. Plant Physiology 111: 137-145.

FARRAR J.F. 1988. Physiological buffering. In: M. Galun (ed.) CRC Handbook of Lichenology, vol. 2. CRC Press., Boca Raton: 101-105.

GIEŁWANOWSKA I. 2005. Specyfika rozwoju antarktycznych roślin naczyniowych Colobanthus quitensis (Kunth) Bartl. i Deschampsia antarctica Desv. 112. Wydawnictwo Uniwersytetu Warmińsko-Mazurskiego w Olsztynie, Olsztyn: 150 pp.

GieŁwanowska I., BocheneK A., GojŁo E., Górecki R., Kellmann W., PastorczyK M. and SzCZUKA E. 2011. Biology of generative reproduction of Colobanthus quitensis (Kunth) Bartl. from King George Island, South Shetland Island. Polish Polar Research 32: 139-155.

GieŁWANOWSKA I., PASTORCZYK M. and KELLMANN-SOPYŁA W. 2011a. Influence of environmental changes on physiology and development of polar vascular plants. Papers on Global Change 18: 53-62.

GROBE C.W., RUHLAND C.T. and DAY T.A. 1997. A new population of Colobanthus quitensis near Arthur Harbor, Antarctica: correlating recruitment with warmer summer temperatures. Arctic, Antarctic and Alpine Research 29: 217-221.

GuY C.H.L., HuBER J.L.A. and HuBER S.C. 1992. Sucrose phosphate synthase and sucrose accumulation at low temperature. Plant Physiology 100: 502-508.

HARE P.D. and CRESS W.A. 1997. Metabolic implications of stress-induced proline accumulation in plants. Plant Growth Regulation 21: 79-102.

HoEKstRa F.A., Golovina E.A. and BuITINK J. 2001. Mechanisms of plant desiccation tolerance. Trends in Plant Science 6: 431-438.

JANSKÁ A., MARŠíK P., ZELENKOVÁ S. and OveSnÁ J. 2010. Cold stress and acclimation-what is important for metabolic adjustment? Plant Biology 12: 295-405. 
JENNINGS D.H. and LYSEK G. 1996. Fungal biology: understanding the fungal lifestyle. BIOS Scientifc Publishers, Guildford, UK: 156 pp.

Kellmann-SopyŁa W., LahUta L.B., GieŁwanowsKa I. and GóReCKi R.J. 2015. Soluble carbohydrates in developing and mature diaspores of polar Caryophyllaceae and Poaceae. Acta Physiologiae Plantarum 37: 118.

Koster K.L. 1991. Glass formation and desiccation tolerance in seeds. Plant Physiology 96: 302-304.

KratsCH H.A. and WiSE R.R. 2000. The ultrastructure of chilling stress. Plant Cell and Environment 23: 337-350.

LACKEY K.H., POPE P.M. and JOHNSON M.D. 2003. Expression of 1L-moy-inositol-1-phosphate synthase in organelles. Plant Physiology 132: 2240-2247.

LAPOLLA A., TRALDI P. and FEDELE D. 2005. Importance of measuring products of non-enzymatic glycation of proteins. Clinical Biochemistry 38: 103-115.

LEPRINCE O., HENDRY G.A.F. and MCKERSIE B.D. 1993. The mechanisms of desiccation tolerance in developing seeds. Seed Science Research 3: 231-246.

LINEBERGER D.R. and STEPONKUS P.L. 1980. Cryoprotection by glucose, sucrose, and raffinose to chloroplast thylakoids. Plant Physiology 65: 298-304.

MORSE E.E. 1947. Anthrone in estimating low concentration of sugar. Analytical Chemistry 19: $10-12$.

Newsted W.J., Chibbar R.N. and Georges F. 1991. Effect of low temperature stress on the expression on sucrose synthase in spring and winter wheat plants. Development of monoclonal antibody against wheat germ sucrose synthase. Biochemistry and Cell Biology 69: 36-41.

OlaVe-Concha N., Bravo L.A., RuIZ-LARA S. and CorCUERA L.J. 2005. Differential accumulation of dehydrin-like proteins by abiotic stresses in Deschampsia antarctica Desv. Polar Biology 28: 506-513.

Olech M., WęGrZYN M., Lisowska M., SŁABY A. and NAgIEL P. 2011. Contemporary changes in vegetation of Polar Regions. Papers on Global Change 18: 35-51.

Parnikoza I., Convey P., Dykyy I., Trokhymets V., Milinevsky G., Tyshchenko O., InoZEMTSEVA D. and KOZERETSKA I. 2009. Current status of the Antarctic herb tundra formation in the Central Argentine Islands. Global Change Biology 15: 1685-1693.

PARNIKOZA I., KOZERETSKA I. and KUNAKH V. 2011. Vascular Plants of the Maritime Antarctic: Orgin and Adaptation. American Journal of Plant Sciences 2: 381-395.

PASTORCZYK M., GIEŁWANOWSKA I. and LAHUTA L.B. 2014. Changes in soluble carbohydrates in polar Caryophyllaceae and Poaceae plants in response to chilling. Acta Physiologiae Plantarum 36: 1771

Piotrowicz-CieŚlaK A.I., GieŁWANOWSKa I., BOCHENEK A., LORO P. and GóRECKI R.J. 2005. Carbohydrates in Colobanthus quitensis and Deschampsia antarctica. Acta Societatis Botanicorum Poloniae 74: 209-217.

Proels R.K. and HÜCKELHOVEN R. 2014. Cell-wall invertases, key enzymes in the modulation of plant metabolism during defence responses. Molecular Plant Pathology 15: 858-864.

RAUSCH T. and GREINER S. 2004. Plant protein inhibitors of invertases. Biochimica et Biophysica Acta 1696: 253-261.

Reyes M.A., Corceuera L.J. and CARDEMIL L. 2003. Accumulation of HSP70 in Deschampsia antarctica Desv. leaves under thermal stress. Antarctic Science 15: 345-352.

Reyes-Diaz M., UlloA N., ZỦÑIgA-Feest A., GutierreZ A., GideKel M., Alberdi M., CorCUERA L.J. and BRAVO L.A. 2006. Arabidopsis thaliana avoids freezing by supercooling. Journal of Experimental Botany 57: 3687-3696. 
ROITSCH T. and GONZALEZ M.C. 2004. Function and regulation of plant invertases: sweet sensation. Trends in Plant Science 9: 606-613.

Rojo E., Zouhar J., CARTer C., Koraleva V. and RaIKHEl N.V. 2003. A unique mechanism for protein processing and degradation in Arabidopsis thaliana. Proceedings of the National Academy of Sciences of the United States of America 100: 7389-7394.

Rolland F., BAENA-GonZALEZ E. and SHEEN J. 2006. Sugar sensing and signaling in plants: conserved and novel mechanisms. Annual Review Plant Biology 57: 675-709.

SolHAUG K.A. and AARES E. 1994. Remobilization of fructans in Phippsia algida during rapid inflorescence development. Plant Physiology 91: 219-225.

SöLLING H. and EsSMAN V. 1975. A sensitive method of glycogen determination in the presence of interfering substances utilizing the filter-paper technique. Analytical Biochemistry 68: 664-668.

SUNG S.J.S., XU D.P., and BLACK C.C. 1989. Identification of actively filling sucrose sinks. 1. Plant Physiology 89: 1117-1121.

TARAN N.Y.U., StoroZHENKo V.O., SVIETLOVA N.B. and TOPCHIY N.M. 2012. Lipids and pigment-protein complexes of photosynthetic apparatus of Deschampsia antarctica Desv. Plants under UV-B radiation. Biopolymers Cell 28: 39-43.

VAN DEN ENDE W. and VALLURU R. 2009. Sucrose, sucrosyl oligosaccharides, and oxidative stress: scavenging and salvaging? Journal of Experimental Botany 60: 9-18.

VARGAS W., CUMINO A. and SALERNO G.L. 2003. Cyanobacterial alkaline/neutral invertases. Origin of sucrose hydrolysis in the plant cytosol? Planta 216: 951-960.

VECCHIA F.D., ASMAR T., CALAMASSI R. and RASCIO C.V. 1998. Morphological and ultrastructural aspects of dehydratation and rehydratation in leaves of Sporobolus stapfianus. Plant Growth Regulation 24: 219-228.

XIONG F.S., Mueller E.C. and DAY T.A. 2000. Photosynthesis and respiratory acclimation and growth response of Antarctic vascular plants to contrasting temperature regimes. American Journal of Botany 87: 700-710.

ZỦÑIGA G.E., ALBERDI M. and CORCUERA L.J. 1996. Non-structural carbohydrates in Deschampsia antarctica Desv. from South Shetland Islands, Maritime Antarctic. Environmental Experimental Botany 36: 393-398.

ZỦÑIGA-FeEST A., BASCUÑÁN-Godoy L., REYES-DiaZ M., BRAVo L.A. and CoRCUERA L.J. 2009. Is survival after ice encasement related with sugar distribution in organs of the Antarctic plants Deschampsia antarctica Desv. (Poaceae) and Colobanthus quitensis (Kunth) Bartl. (Caryophyllaceae)? Polar Biology 32: 583-591.

Received 23 Jan 2017

Accepted 14 February 2017 